\title{
Study of Abnormal Foramen Over the Posterior Arch of Atlas Vertebra
}

\section{Estudio de Forámen Anormal sobre el Arco Posterior de la Vértebra Atlas}

"Vijaykumar Shankar Shinde \& ** Mallikarjun, M.

SHINDE, V. S. \& MALLIKARJUN, M. Study of abnormal foramen over the posterior arch of atlas vertebra. Int. J. Morphol., 30(2):557-558, 2012.

SUMMARY: The aim of this research was to study the anatomical aspects of abnormal foramen over the posterior arch of atlas vertebra. Posterior arch of atlas vertebrae was studied for abnormal foramen in sixty-seven adult human atlas vertebrae and findings were noted. In $2.98 \%$ of cases, unilateral complete abnormal foramen on the posterior arch of atlas vertebra was found. Clinicians should be aware about this variation on posterior arch of atlas, which may produce headache, vertigo, vertebrobasilar insufficiency and shoulder pains.

KEY WORDS: Atlas; Vertebra; Posterior arch; Foramen; Bony bridge; Groove.

\section{INTRODUCTION}

The first cervical vertebra is called as atlas vertebra which does not have a body. It has two arches, anterior and posterior. The posterior arch is longer than anterior arch and represents a groove on its superior surface for third part of vertebral artery and dorsal ramus of first cervical spinal nerve. Normally third part of vertebral artery comes out of foramen transversarium of atlas vertebra and lies on the groove over the superior surface of posterior arch. In some cases, this groove on the posterior arch may get converted in to complete or partial bony foramen (Standring, 2005). This abnormal foramen is studied in detail.

\section{MATERIAL AND METHOD}

Sixty seven (67) dry, adult human atlas vertebrae collected from north Karnataka region were studied for abnormal foramen on the superior surface of posterior arch of atlas vertebra and location, extent, unilateral or bilateral, type of foramen, whether completely or partially formed were studied.

\section{RESULTS}

Sixty seven adult human atlas vertebra were studied. Out of these, in 2 cases $(2.98 \%)$ completely ossified unilateral bony foramen was found over the superior surface of posterior arch. In this case one was on left side and the other was on right side of posterior arch. which were roughly circular in shape, $3 \mathrm{~mm}$ from the root of posterior arch, measuring $4-5 \mathrm{~mm}$ in diameter. It is shown in photo 2 with tying threads.

In two vertebrae, partial or incompeletely ossified bilateral abnormal foramen was found on right arch (Fig. 1).

\section{DISCUSSION}

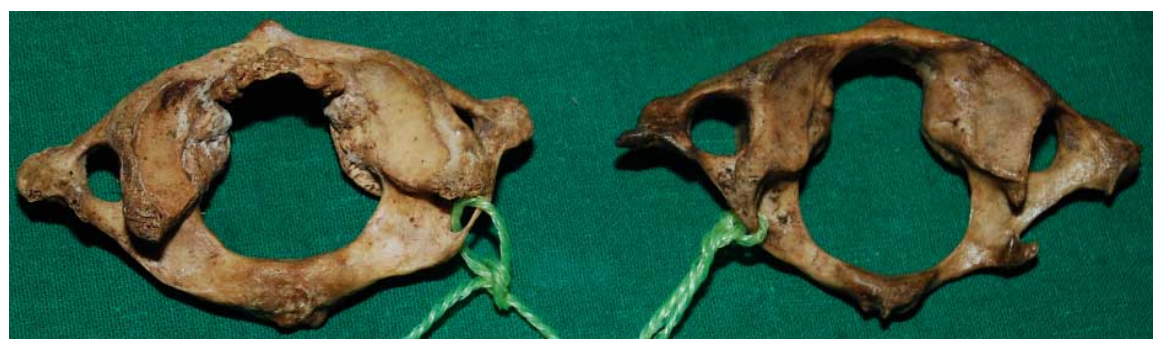

Among the cervical vertebrae, atlas vertebra shows many variations with respect to foramena transversaria, abnormal foramen on the posterior arch and fusion of atlas vertebra with occipital bone (Nayak et al., 2005). Hasan et al. (2001) classified this abnormal foramen in to six groups.

Fig. 1. Partial or incompeletely ossified bilateral abnormal foramen in the atlas.

\footnotetext{
* Assistant Professor, Department of Anatomy, VIMS, Bellary, Karnataka, India.

${ }^{* *}$ Professor \& HOD, Department of Anatomy, VIMS, Bellary, Karnataka, India.
} 
Many authors have studied about this foramen previously and have found its occurrence in $9.8-25.9 \%$ of cases (Young et al., 2005; Mitchell, 1998).

Paraskevas et al. (2005) noted higher occurrence of complete canal for vertebral artery in labourers compared to that of nonlabourers, reveling chances of protective mechanism of the bony canal. He also noted the higher incidence of canal in the 5-44 years of age group.

Taitz \& Nathan (1986) proposed a hypothesis that carrying heavy objects on head and other mechanical factors may play a role in development of these bony foramen. $\mathrm{He}$ also found the occurrence of partial posterior bridging of atlas in $25.9 \%$ and complete bridging in $7.9 \%$ of cases.

Bergman et al. (1988) reported that atlas vertebra may show incomplete ossification of anterior and posterior arches and posterior arch may show fecet or tunnel for vertebral artery. Ossification of ligaments, foramen of bony bridges around vessels may produce compression effects and may interfere with regional surgeries (Limousin, 1980). Cushing et al. (2001) noted the tethering of the vertebral artery in the abnormal bony canal.

Clinicians should have awareness regarding this bony abnormal foramen in patients with neck pain, shoulder pain, vertigo, and headache complaints. Cervical spine radiography is helpful to make out arcuate foramen (Cakmak et al., 2005).

This abnormal bony foramen may lead difficulty for instrumentation in this area. It may also hinder the blood flow in vertebral artery (Bilodi \& Gupta, 2005).

In conclusion, although some authors proposed hypothesis that presence abnormal bony foramen may have a protective role for vertebral artery, but it may also produce compression effect and may hinder blood supply to vertebral artery. physicians, surgeons, neurologists, neurosurgeons, anaesthetists and radiologists should be aware about this variation on posterior arch of atlas vertebra which may produce head ache, vertigo, vertebrobasilar insufficiency and unexplained shoulder pains.

SHINDE, V. S. \& MALLIKARJUN, M. Estudio del foramen anormal sobre el arco posterior de la vértebra Atlas. Int. J. Morphol., 30(2):557-558, 2012.

RESUMEN: El objetivo fue observar los aspectos anatómicos de un foramen anormal presente sobre el arco posterior del atlas. Se estudiaron 67 vértebras atlas de humanos adultos. En el 2,98\% de los casos, se encontró un foramen unilateral anormal completo sobre el arco posterior del atlas. Los clínicos deben estar conscientes de esta variación anatómicaen , la cual podría producir cefalea, vértigo, insuficiencia vertebrobasilar y dolores en los hombros.
PALABRAS CLAVE: Atlas; Vértebra; Arco posterior; Foramen; Puente óseo; Foramen.

\section{REFERENCES}

Bergman, R. A.; Afifi, A. K. \& Miyauchi, R. Skeletal systems: Cranium. In: Compendium of human anatomical variations. Baltimore, Urban and Schwarzenberg, 1988. pp.197-205.

Bilodi, A. K. \& Gupta, S. C. Presence of retro transverse groove or canal in atlas vertebrae. J. Anat. Soc. India, 54:10-8, 2005.

Cakmak, O.; Gurdal, E.; Ekinci, G.; Yildiz, E. \& Cavdar, S. Arcuate foramen and its clinical significance. Saudi Med. J., 26(9):1409-13, 2005.

Cushing, K. E.; Ramesh, V.; Gardner-Medwin, D.; Todd, N. V.; Gholkar, A.; Baxter, P. \& Griffiths, P. D. Tethering of the vertebral artery in the congenital arcuate foramen of the atlas vertebra: a possible cause of vertebral artery dissection in children. Dev. Med. Child. Neurol., 43(7):491-6, 2001.

Hasan, M.; Shukla, S.; Siddiqui, M. S. \& Singh, D. Posterolateral tunnels and ponticuli in human atlas vertebrae. J. Anat., 199(Pt 3):339-43, 2001.

Limousin, C. A. Foramen arcuale and syndrome of Barre-Lieou. Its surgical treatment. Int. Orthop., 4(1):19-23, 1980.

Mitchell, J. The incidence of the lateral bridge of the atlas vertebra. $J$. Anat., 193( Pt 2):283-5, 1998.

Nayak, S.; Vollala, V. R. \& Raghunathan, D. Total fusion of atlas with occipital bone: a case report. Neuroanatomy, 4:39-40, 2005.

Paraskevas, G.; Papaziogas, B.; Tsonidis, C. \& Kapetanos, G. Gross morphology of the bridges over the vertebral artery groove on the atlas. Surg. Radiol. Anat., 27(2):129-36, 2005.

Standring, S. Grays Anatomy. 39th ed. London, Churchill Livingstone, 2005. pp.735-45.

Taitz, C. \& Nathan, H. Some observations on the posterior and lateral bridge of the atlas. Acta Anat., 127(3):212-7, 1986.

Young, J. P.; Young, P. H.; Ackermann, M. J.; Anderson, P. A. \& Riew, K. D. The ponticulus posticus: implications for screw insertion into the first cervical lateral mass. J. Bone Joint Surg. Am., 87(11):2495-8, 2005.

Correspondence to:

Dr. Vijaykumar S. Shinde MD,

Assistant Professor,

Department of Anatomy

VIMS, Bellary.

Karnataka State

INDIA

Email: drvijaykumarss@gmail.com

Received: 10-11-2011

Accepted: 03-02-2012 